The Original Meaning of the Fourteenth Amendment 



\title{
The Original Meaning of the Fourteenth Amendment
}

\author{
Its Letter and Spirit
}

\author{
RANDY E. BARNETT
}

EVAN D. BERNICK

Foreword by

JAMES OAKES

THE BELKNAP PRESS OF

HARVARD UNIVERSITY PRESS

Cambridge, Massachusetts

London, England

$2 \mathrm{O} 2 \mathrm{I}$ 
Copyright (C) 2021 by the President and Fellows of Harvard College All rights reserved

Printed in the United States of America

$$
\begin{gathered}
\text { First printing } \\
\text { Jacket design by Gabriele Wilson } \\
9780674270138 \text { (EPUB) } \\
9780674270 \text { I2I (PDF) }
\end{gathered}
$$

The Library of Congress has cataloged the printed edition as follows:

Names: Barnett, Randy E., author. | Bernick, Evan D., author. | Oakes, James, writer of foreword.

Title: The original meaning of the Fourteenth Amendment : its letter and spirit / Randy E Barnett, Evan D Bernick ; foreword by James Oakes.

Description: Cambridge, Massachusetts : The Belknap Press of Harvard University Press, 202I. | Includes bibliographical references and index.

Identifiers: LCCN 202100936I | ISBN 9780674257764 (cloth)

Subjects: LCSH: United States. Constitution. r4th Amendment. | Privileges and immunities-United States. | Due process of law-United States.

Equality before the law-United States.

Classification: LCC KF 4558 I4th .B 37 202I $\mid \mathrm{DDC}_{342.7308 / 5-\mathrm{dc} 23}$

$\mathrm{LC}$ record available at https://lccn.loc.gov/202100936I 
R A N DY:

To my wife, Beth, my mother, Florice,

and in loving memory of my father, Ronald

EVAN:

To my wife, Sarah, and my parents, Christine and David 
